\title{
Pop-up Book Illustration Art as Expressive and Artistic Communication Media
}

\author{
Satrio Haryanto*, Tri Karyono \\ Pendidikan Seni \\ Universitas Pendidikan Indonesia \\ Bandung, Indonesia \\ *haryantosatrio9@gmail.com, tri3karyono@upi.edu
}

\begin{abstract}
This research uses qualitative paradigm with descriptive analytical approach to obtain an overview on illustration art which are based on and paper engineering, that is called pop-up art. This writing is aimed at revealing development of illustration art in a three-dimensional form through both visual and technical elements of pop-up illustration of a children book. Appearance of pop-up illustration artwork which involves multi techniques and which is closely related with paper craft and handy craft makes it interesting to research due to the fact that most illustration arts use drawing technique which is twodimensional form. While the sample taken in this research is Pop-Up book written by Ida Nissaurrasyidah and from Impian Studio. The research shows that three-dimension illustration, with its uniqueness and with paper mechanism, which is accurate resulting in artistic, expressive pop-up art, educates its readers through its visual communication designed by its illustrator.
\end{abstract} media

Keywords—pop-up book, illustrastion art, communication

\section{INTRODUCTION}

The birth of reformed technology in all life aspects triggers implications on someone's artistic and aesthetic experience. With sophisticated, advanced and developing technology, aesthetic value of handmade artwork will be more acknowledged, valued, appreciated and have higher selling price as well as its idea originality and its unique process of handmade creation will bring impact to meaningful artwork appreciation. The same thing occurs to illustration field. In this digital era, many kinds of illustration appear from twodimensional illustration to application of augmented reality technology on a textbook.

Amidst its development of book illustration applying augmented reality technology, artwork using papercraft offers something unique, creative and artistic through its technical and mechanical use of paper engeenering as it occurs in pop- $u$ art, which has visually attraction in its surprising look. In the beginning, pop-up art was recognized as moveable book (in around $13^{\text {th }}$ century), with its simple construction, like volvelles (rotary) technique, which made use of its central axis on mechanical paper arrangement. about the development of Pop- up books, a children's book editor, said "in 1514-1564 movable book was used for medical field by oleh Andreas Vesalius in arranging book about human anatomy. Hence, the term lift the flap became popular in medical society. Then in 1765 the publisher Robert Sayer published lift the flap book for children book and this got astonishing appreciation for children motoric development. In 1930-es, in United States of America the term pop-up was initially used and it is still used up to now" [1]. The term became popular because of its pop-up characteristic had uniqueness of dimension or space impression which was made ad which creates surprising effect from paper mechanical movement designed.

Illustration artwork traditionally is grouped into applicative artwork in two-dimension form but now has been developed into three-dimensional form. Three-dimensional illustration artwork on a book exists to give realistic explanation on a topic and with it, the grouping of two-dimension pop-up illustration of illustration artwork is no longer necessary [2]. Threedimension illustration, like we find in three-dimension illustration pop-up book, showing artwork visualization which are interrelated with other arts like photography, collage, montage, origami, kirigami, paper craft, paper engineering, graphic design, and visual communication design. Ilustration on book usually uses drawing technique on two-dimension media, then it developed into pop-up illustration which is multi techniques so that it requires a particular like handcraft in its creation.

Pop-up on a book page is known as the term is used to differentiate pop-up card which is usually made on one piece of greeting card. Related to this, Amalia claimed "the use of pop-up media in the learning process will it attracts more attention and can foster students' motivation to learn" [3]. Textbook using pop-up (papercraft) base will be different from other textbooks not using pop-up or papercraft. Pop-up book is more educating, unique and creates surprise and amazement when the book is open. Surprising effect in pop-up book triggers high curiousity. Creator pop-up book pointed out that "Pop-up book is a book which pop to the surface in threedimension way. The book triggers imagination of the readers through the manipulation of space and perspectives" is a book that emerges in three dimensions, a book that can spark readers' 
imagination through spatial engineering and perspective. In line with opinion stated by Taylor dan Bluemel [4] which says that:

"Pop-up books are made up from formats of mechanical, movable books, that unfold and rise from the page to our surprise and delight. Pop-up books include construction, the movement of the book that appears from the page that makes us surprised and pleased" [4]. In line with the statement, Stephan Van Dyk [5], an engineer paper from Washington DC stated in his journal;

"Pop-up book has been delighting and engaging readers and non-readers, young and old respectively, for nearly 800 years. Using inventive ways to fold paper and create movement, popup artists and paper engineers transform the printed page from two-dimensional forms to three-dimensional experiences. For nearly 800 years, pop-up books have caught the attention of readers and non-readers, young and old. Pop-up books are made using creative ways to fold paper and create movements. Pop-up book maker converts printed pages from twodimensional to three-dimensional" [5].

Another opinion says that a pop-up book is a book that has moving parts or has three-dimensional elements and provides a more interesting visualization of the story, starting from the display of images that can move when the page is opened [6]. In accordance to Bluemel and Taylor, explain that a Pop-up book is a book that displays the potential for movement and its interactions through the use of paper as a material for its folds, rolls, wheels or turns [4].

Based on the various opinions above, a pop-up book can be interpreted as a unique and artistic three-dimensional interactive book. Researchers appreciate the pop-up book as part of a communicative, expressive and artistic handmade illustration technique. This article describes the visual elements and techniques of a pop-up book. The pop-up bookcase studies that were the samples of this research were the pop-up book by Impian Studio and the work of Ida Nisaurrasyidah, a pop-up creator as a comparison [7]. The purpose of writing this article is to determine the visual elements and techniques used in the pop-up book by Impian Studio and by Ida Nisaurrasyidah. The benefits of writing this article are understanding and knowing the visual elements and techniques used in pop-up book illustrations.

The two samples were chosen because Impian Studio popup books have created pop-up books that are very educational and inspiring. Impian Studio has been recognized as a pioneer in releasing pop-up books in Indonesia since 2004. They published books with very detailed three-dimensional effects. Moreover, the pop-up book by Ida Nissaurrasyidah has its own uniqueness. The process of character study and sketching to coloring is done directly and manually with various drawing techniques such as quarel, block, paper craft and paper mechanical designing techniques. The pop-up technique designed by Ida Nissaurrasyidah is made by relying on skill and hand (handmade) skills, but the results are very neat, the tidiness and finishing are excellent, presented in the form of illustrated story book with an artistic cover design.

There are five basic techniques in making pop-up works such as (1) the $V$-folding technique. This technique makes a folding panel on the side of the image that will be attached to form the letter V. (2) the internal stand, made by cutting paper that is folded vertically as a backrest then given a panel to attach the illustration to when opened the pop-up will stand up. (3) Rotary, a rotary / rotary mechanism is used to visualize the effect of a rotating movement. (4) Open Mout, the construction of this technique resembles a wide-open mouth. This effect is designed for mouth visualization- an animal that seems to pounce on its prey. (5) Parallel slide \& Pull slide technique, slide or pull, is designed to create the impression of moving, walking or sliding by dragging or sliding the panels that have been prepared. In rotary, parallel slide and pull techniques do not display shapes that arise upward, pop-ups do not always have to appear upward (up), but it can also be presented with a movement effect that creates the impression of moving, shifting, rotating, or being drawn but still visible. dimensionless. Regarding the basic technique of pop-up books, Alit Ayu, emphasized that pop-ups do not always appear in an arising form, but rather appear with a movement that creates an impression that appears / has dimensions [8]. Pop-ups that are applied to story books usually combine the five techniques in one book. As done by Ida Nisaurrasyidah in making the pop-up story Nusantara book "Timun Mas" [7]. combines 5 basic popup techniques, as well as a pop-up book made by Impian Studio that applies various techniques in each of his books.

\section{RESEARCH METHODS}

This writing applies a qualitative method with a descriptive analytical approach. Based on observations through literature studies and information related to pop-up book works, the research subjects were Impian Studio and Ida Nisaurrasyidah as a pop-up book creator [7]. Data collection was conducted by field observations, interviews and documentation of book shoots, assembly and other supporting aspects of the pop-up book making process. Furthermore, the data is reduced, summarized and analyzed.

\section{FINDINGS AND DISCUSSION}

Pop-up visual elements can be observed in the balance of the layout of the illustration image, text / writing and the construction of the pop-up panel. The right composition will avoid the impression of being biased on the media filled with visual elements. In general, pop-up techniques use a central composition in the middle of the book page, such as the $\mathrm{V}$ folds, cylinder box, mout and under standup technique. However, in the pull tab technique, rotary and flip the flap, diagonal and asymmetric compositions are the right choices. The design of the pop-up technique considers the principle of balance so that mechanical paper can work well according to the illustrator design. 
Pop-up visual elements appear on the principle of unity between parts of other visual elements. In pop-up illustrations, the principle of unity is used to harmonize all visual elements, such as layouts, typography, illustration images, cover designs, composition, colors and character letters which are designed to be interrelated and united to form a harmonious and aesthetic visualization so that concepts and ideas are communicated well to the reader.
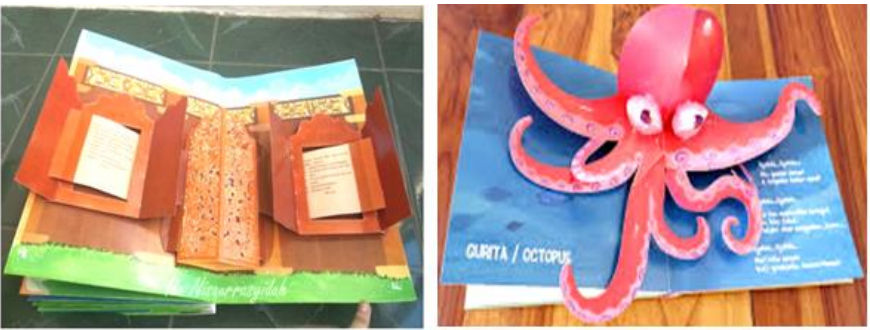

Fig. 1. Principle of balance and unity on pop-up books.

Another visual element that appears in the pop-up illustration is the book cover design (figure 1). Book cover provides an overview of the contents of the book globally. Attractive design, unique, colorful and clever graphic design processing, will attract appreciators. Typography letters and representative graphic layout are the main keys to attract readers. From 2 sample pop-up books that the author researched, processing the type and size of letters in the book title emphasizes the author's concepts and ideas and the selection of the right coloring provides an artistic and a more expressive visual effects so that the message / information of a book is well communicated. As in the display of the pop-up book with the unique title wiu..wiu..wiu ..which tells the story of 3 types of vehicles that have a siren and sound wiu..wiu , the processing of letters in book titles is different from large to small with the composition of asymmetrical diagonals as a visual representation of sound waves and pressing sirens on fire engines and police cars. Meanwhile, the cover design by Ida Nissaurasyidah presents a different visual, the skill in drawing is felt in the creation of the characters of Timun Mas and Buto Ijo and the color gradations that are processed in expressive detail strengthen the concept of the story (figure 2).

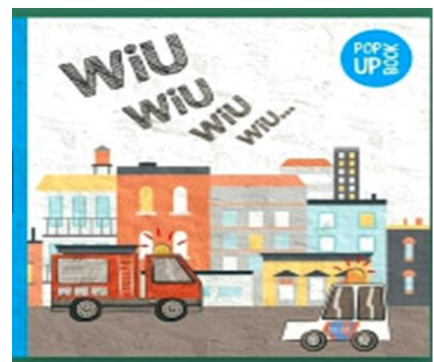

a.

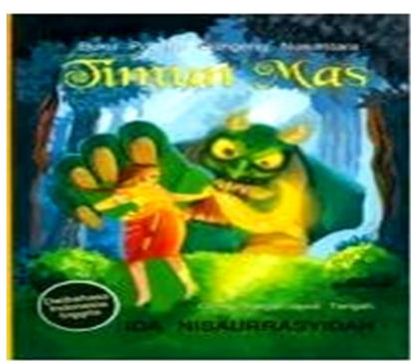

b.
Fig. 2. (a) Book cover of Impian Studio (b) Pop-up book cover by Ida Nisaurrasyidah [7].

Based on the results of observations, there are several popup techniques that the author found from two samples of research pop-up book by Dream Studio and by Ida
Nissaurasyidah. The first construction of the pop-up technique that the writer found is the $\mathrm{V}$-folding technique. Dimension calculations for books, pop-up construction, folding techniques and techniques for sticking paper panels are the main keys in visualizing pop-up illustrations, such as in the pop-up book "day and night" by Impian Studio (figure 3), which tells about differences between day and night, and what happens during lap time. This book consists of 5 pages with full pop ups and pull tabs. the paper's accurate mechanical construction results in a pop-up illustration of a tree with leafy and expanding leaves that can appear when the book page is opened. The use of different color tones between dark and light and different illustration objects on the other side gives effect and emphasis to the content of the text so that the purpose of conveying information about the difference in atmosphere between day and night is very vivid. Likewise, the visualization of the Buto Ijo character in the story "Timun Mas" by Ida Nissaurrasyidah (figure 3), the accurate construction and design made the giant Buto Ijo visual object appear vertically along with the illustration of the Timun Mas' house. Narrative text and typeface made with a short, solid editorial, with clear and straightforward language, are very appropriate to be used as reading books for children.
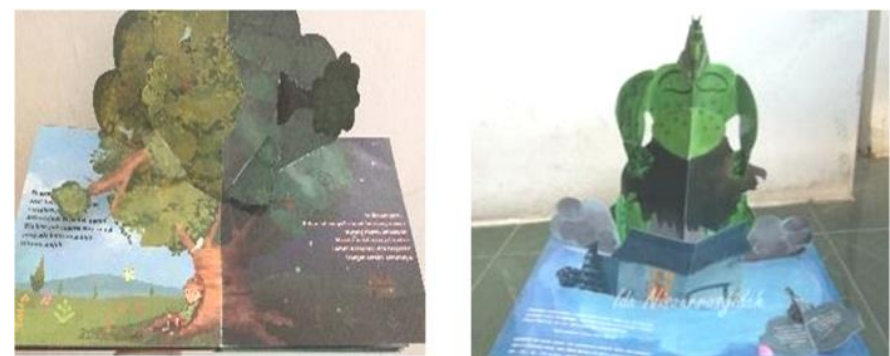

Fig. 3. Pop-up illustration of a tree and Buto Ijo character with V-folding technique.

The next technique the writer found was the box / cylinderup technique. The combination of two different techniques appears in the book entitled "wiu..wiu..wiu" which tells of three vehicles that have sirens and sound wiu, namely police cars, ambulances, and fire engines (figure 4). The pop-up technique that is presented is in the form of a square box, beam or cylinder, the construction of the panel fold shaft is in the middle of the book page attached to both sides of the book sheet, similar to the $\mathrm{v}$-folding technique, but in this technique the object that arises is three-dimensional which can be seen from the various directions. The impression of space from a complete form is felt. The same visualization is also felt in the character of a beautiful little baby who comes out of a large golden cucumber (figure 4). On the left side of the book, there is a flip the flap technique to balance the composition and strengthen the storyline so that the pop-up visualization becomes morelively and interesting. 


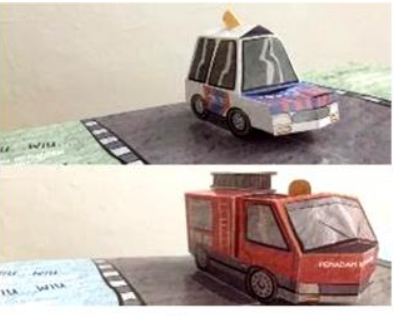

a.

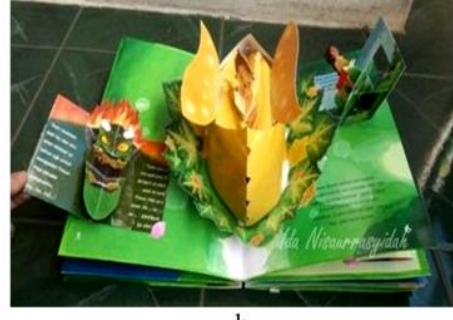

b.
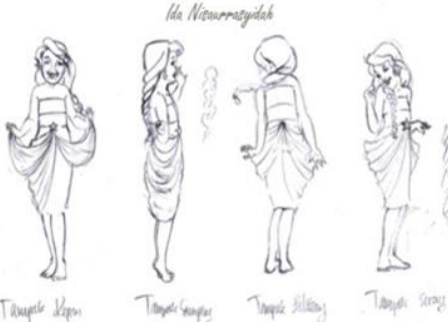

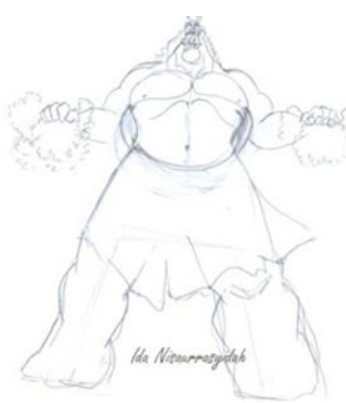

Fig. 4. (a) Vehicle visualization using box-up technique and (b) Timun Mas baby character.

Another technique that is applied to pop-up books is pull and slide, this technique makes the reader seem to interact directly with the storyline and stimulates motor sensors in children. The motion interaction of this technique makes the reader interested in understanding the story / text content and arouses curiosity. The visualization of an ambulance driving with a sliding panel conveyed a message about the importance of making way for medical personnel carrying sick people. Another similar finding, found in the vertical pull technique designed by Ida Nissaurrasyidah (see figure 5), suggests space and perspective on the giant Buto green scene drowning in a sea of shrimp paste mud. The concept of the pop-up point of view created is very unique and stimulates the imagination. The illustrator's idea of visualizing text / word language into visual language is well communicated, especially the emphasis on the bird's eye perspective effect using imaginative vertical pull techniques.

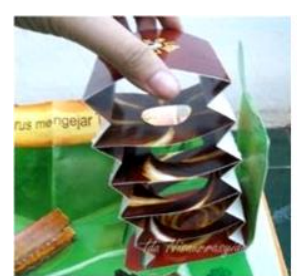

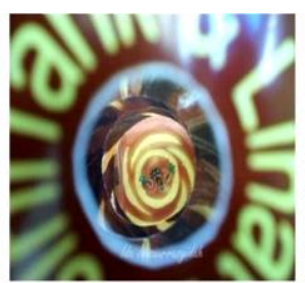

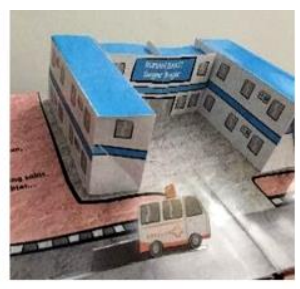

Fig. 5. (a) Pull vertical technique (b) Bird eye view perspective, (c) Pull horizon technique.

\section{A. Pop-up Books Creating Process}

Pop-up books are made with a fairly long process, starting from creating concepts and ideas to the stage of creating a popup book. The process of making a pop-up book is as follows:

1) Concepts and ideas: The concept of ideas and ideas can be in the form of a story script that is intended for making picture story books. The text is written and packaged in a language style and story line according to the age level of the reader and based on the theme of the story.

2) Character creation: The process of creating characters on the theme of fictional stories or fairy tales requires imagination and compatibility among themes, characterizations, backgrounds, settings and storylines, so that they are more realistic and can be realized in an attractive visual language (see figure 6).

Fig. 6. Sketch character Timun Mas \& Buto Ijo.

3) Storyline board: The storyline board is made so that the series of stories and illustrations can be designed and adjusted to the theme of the story and the concept of ideas planned by the illustrator as well as the paper mechanical panel size design for the pop-up technique to be used (see figure 7).

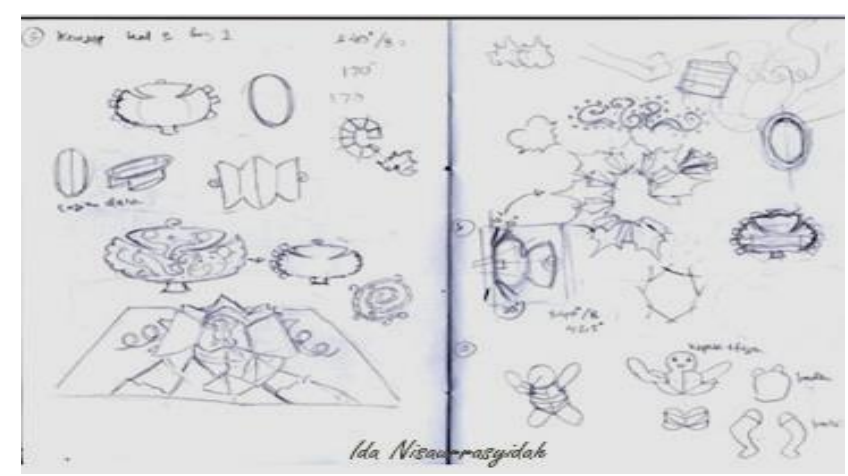

Fig. 7. Storyboard pop-up book Timun Mas.

4) Sketching and coloring: The character of the character is made based on the character study that has been done. Sketches and coloring of illustrated images can be made manually or with digital assistance and then scanning is carried out for transformation in the printing process on prepared paper (see figure 8).
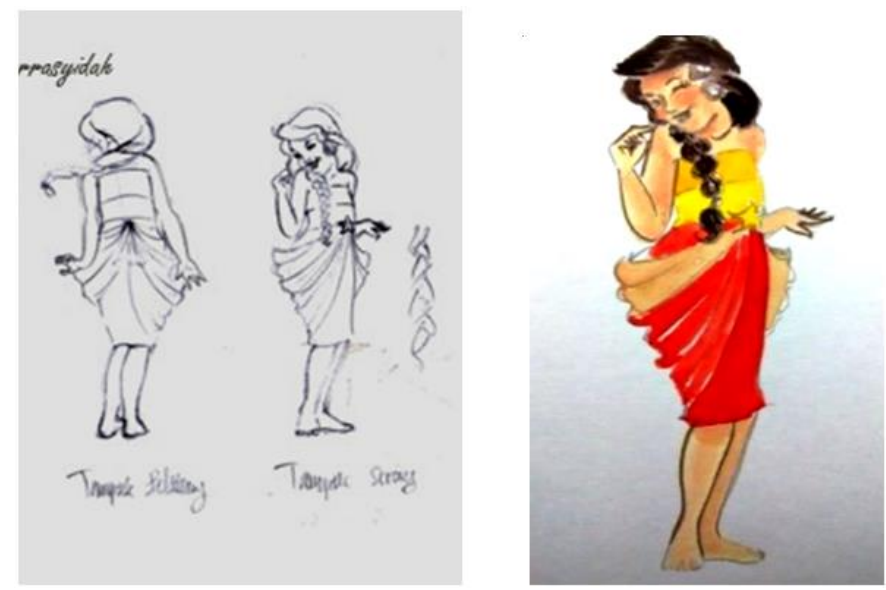

Fig. 8. Drawing \& coluring character. 
5) Cutting: Illustration images that have been colored with manual or digital techniques and construction panels that have been designed are united on the image, then printed on certain paper to be cut or cut according to the prepared pop-up design. The cutting process can be done at once using a pond machine or manually using scissors and a cutter (see figure 9).

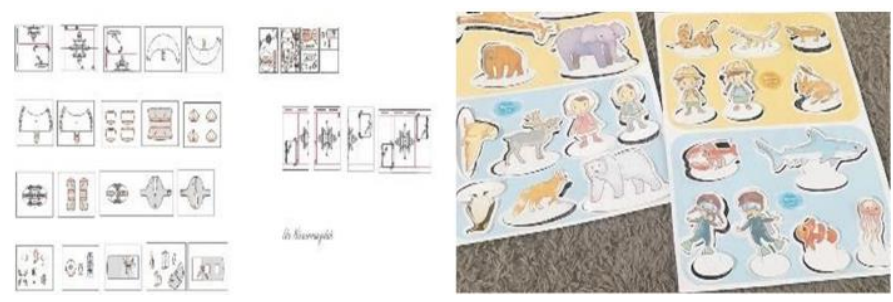

Fig. 9. Pop-up illustration and printed construction panel ready to cut.

6) Prototype / white dummy: White dummy is the term for pop-up book design. The term white is used because it uses white paper, like the term blueprint, in general, on blue colored paper. At this stage, the accuracy of paper size, dimensions and mechanics are tested so that the construction of pop-up panels can operate properly (see figure 10).

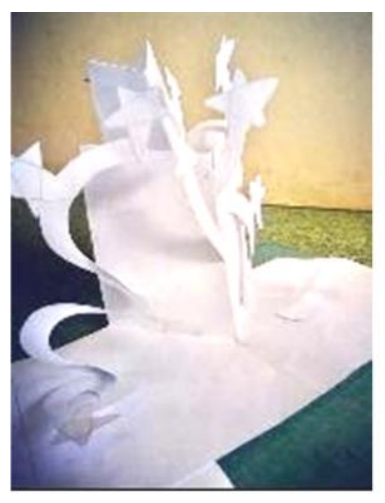

a.

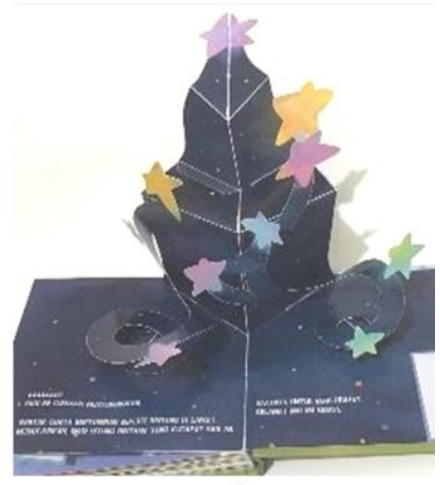

b.
Fig. 10. (a) White dummy (b) End result

7) Assemble the panels: This stage begins with assembling pop-ups and paper mechanical construction that will be applied to each sheet of the book. Assembly is done by connecting each parts of the illustration image along with the paper panels that are designed beforehand. The technique of gluing the glue really determines the quality of the tidiness and mechanical resistance of the working paper.

8) Finishing: The final process is to provide a book cover design covered with a laminate to be resistant to water and damage and to add aesthetic image to reading books.

9) Packing and distribution: The last stage is book packaging to be sent and traded either through a bookstore or to be sent directly to the customer.

\section{CONCLUSION}

Pop-up book illustration is the development of -two dimensional applied fine arts into three-dimensional forms. Appearance of pop-up book illustration artwork which involves multi techniques and which is closely related with paper craft and handy craft. Illustration art pop-up with its uniqueness and with paper mechanism is accurate resulting in artistic, expressive illustration art, educates its readers through its visual communication designed by its illustrator.

\section{REFERENCES}

[1] N.H. Dee, "Sejarah singkat buku Pop-up," 2017. [Online] Retrieved from: http://sastranak.blogspot.com/2017/03/sejarah-singkat-buku-popup_28.html

[2] S. Salam, Seni Ilustrasi: Esensi, Sang Ilustrator, Lintasan, Penilaian. Makasar: Badan Penerbit UNM, 2017.

[3] S. Amalia, Penggunaan Media Pop-Up Book Untuk Meningkatkan Hasil Belajar Menggambar Ilustrasi Pada Siswa Kelas V SDN Umbul Kapuk. Bandung: Universitas Pendidikan Indonesia, 2017.

[4] N. Bluemel and R.L.H. Taylor, Pop-up Books A Guide For Teachers and Librarians. California: ABC-CLJO, LLC, 2012.

[5] S.V. Dyk, Paper Enginering. Washington DC: Smithsonian Instittion Libraries, 2010.

[6] B. Dzuanda, Perancangan Buku Cerita Anak Pop Up, Tokoh-Tokoh Wayang Berseri, Seri "Gatotkaca"(Tugas Akhir). Surabaya: Institut Teknologi Sepuluh Nopember Surabaya, 2009.

[7] A.A. Dewantari, "Sekilas Tentang Pop-UP,Lift the Flap dan Movable Book," 2014. [Online] Retrieved from: http://dgi.or.id/read/observation/sekilas-tentang-pop-up-lift-the-flap-danmovable-book.html

[8] I. Nisaurrasyidah, "Proses Visualisasi Buku Dongeng Timun Mas dengan Teknik Pop-Up untuk Pengembangan Kemampuan Komunikasi Anak," ORASI: Jurnal Dakwah dan Komunikasi, vol. 9, pp. 95-110, 2018 